\title{
Solid-Phase Metal Chelate Assay for Quantifying Total Protein: Resistance to Chemical Interference
}

BioTechniques 21:888-897 (November 1996)

\section{Mark J. Lim, Wayne F. Patton, Negin Shojaee and David Shepro}

Boston University, Boston, MA, USA

\section{INTRODUCTION}

Proteins are quantified by a variety of methods based upon different physical principles. UV spectrophotometry utilizes the intrinsic absorptive properties of aromatic amino acids for quantitation $(2,16)$. Though proteins are not chemically altered, the UV method is insensitive and inherently exhibits protein-to-protein variation since the frequency of tryptophan and tyrosine residues varies among different proteins. Turbidimetric methods rely upon protein precipitation and subsequent spectrophotometric analysis $(2,16)$. Trichloroacetic acid is a popular precipitating agent, but nucleic acids can also precipitate and interfere with analysis (2). Also, turbidimetric assays display poor sensitivity and accuracy, high protein-to-protein variation and limited dynamic range (16). Other solution-based techniques, such as the biuret and Folin-Ciocalteau (Lowry) assays, rely upon chemical reactions with proteins to generate a colored product $(2,16)$. These techniques are susceptible to interference from some commonly used reagents that also produce colored product (2). In the solution-based bicinchroninic acid (BCA) protein assay, reduced copper is chelated to two molecules of BCA, yielding a purple product with strong absorbance at 562 $\mathrm{nm}$ (23). The BCA assay is more tolerant to interfering agents, but remains sensitive to reducing agents such as $\beta$ mercaptoethanol (BME) and dithiothreitol (DTT), as well as chelating agents such as ethylenediaminetetraacetic acid (EDTA). Finally, solution- based methods such as the Coomassie Brilliant Blue and pyrogallol redmolybdate assays measure shifts in the wavelength maximum of dye absorbance upon formation of a dye-protein complex $(1,16,26)$. Dye-binding methods are highly tolerant to chemical agents in the sample (2). Most depend upon electrostatic interaction of anionic dyes with $\alpha$ - and $\varepsilon$-amino side-chain moieties at acidic $\mathrm{pH}$ and thus are more subject to protein-to-protein variation than the biuret and Folin-Ciocalteau assays $(5,18,25,27)$.

Many solution-based total protein assays and electrophoresis stains (amido black, Ponceau red, Fast green, BCA, Coomassie Brilliant Blue, FolinCiocalteau, Benzoxanthine yellow, colloidal gold, colloidal iron and India ink) are adaptable to solid-phase assays (4-9,11-15,21,22,24). Solid-phase protein assays are less susceptible to interfering agents commonly found in samples. Since protein is specifically bound to membranes, contaminants are readily washed away. Total protein quantitation is achieved directly on the membrane by densitometry using instrumentation for quantitation of protein bands in polyacrylamide gels. Alternatively, the stains can often be eluted from membranes and quantified by spectrophotometry.

Recently, we developed a sensitive metal chelate stain for proteins electroblotted to nitrocellulose and polyvinyl difluoride (PVDF) membranes (18). The stain is fully reversible and compatible with protein sequencing and immunoblotting (18). It is based upon binding of Ferrozine ${ }^{\circledR} /$ ferrous 
complexes to electroblotted proteins, followed by binding of ferrocyanide/ ferric complexes for enhanced sensitivity. The double-metal chelate (DMC) stain is evaluated in this study for its use in a solid-phase total protein assay. The DMC stain is compared to the Ferrozine/ferrous, BCA and colloidal gold assays with respect to sensitivity, dynamic range, protein-to-protein variation and tolerance to interfering agents.

\section{MATERIALS AND METHODS}

\section{Materials}

Potassium ferrocyanide, 3-(2-pyridyl)-5,6-bis(4-phenylsulfonic acid)1,2,4-triazine disodium salt (Ferrozine), polyvinyl pyrrolidone-40 (PVP40), thioglycolic acid, light white mineral oil, chicken ovalbumin, bovine serum albumin (BSA), bovine gelatin and bovine hemoglobin were obtained from Sigma Chemical (St. Louis, MO, USA). Nitrocellulose membranes, $0.45-\mu \mathrm{m}$ pore size, were obtained from Bio-Rad (Hercules, CA, USA). Nytran membranes, $0.45-\mu \mathrm{m}$ pore size, were obtained from Schleicher \& Schuell (Keene, NH, USA). Ferric chloride was obtained from Matheson Coleman \& Bell (Norwood, OH, USA). Gold chloride was obtained from Polysciences (Warrington, PA, USA).

\section{Dot Blotting}

For analysis of the linear response of the protein assays, dilutions of BSA ranging from $1.5 \mathrm{ng} / \mu \mathrm{L}$ to $10 \mu \mathrm{g} / \mu \mathrm{L}$ were prepared from a $10 \mu \mathrm{g} / \mu \mathrm{L}$ stock in distilled and de-ionized water (dd$\mathrm{H}_{2} \mathrm{O}$ ). All BSA stock solutions were prepared gravitometrically. Interfering agents were prepared as $2 \times$ stocks and mixed with equal volumes of $0.2 \mu \mathrm{g} / \mu \mathrm{L}$ BSA. One microliter of each sample was applied onto nitrocellulose strips ( $n$ $=2$ ). After allowing the membranes to air dry, they were incubated in $0.1 \%$ PVP-40 in phosphate-buffered saline (PBS). The Ferrozine/ferrous complex was prepared as a solution of $0.75 \mathrm{mM}$ Ferrozine, $30 \mathrm{mM} \mathrm{FeCl} 3,15 \mathrm{mM}$ thioglycolic acid in $2 \%$ acetic acid. The ferrocyanide/ferric complex was prepared as a solution of $100 \mathrm{mM}$ potassium ferrocyanide $\left(\mathrm{K}_{4} \mathrm{Fe}(\mathrm{CN})_{6}\right), 60 \mathrm{mM} \mathrm{FeCl}_{3}$, in $100 \mathrm{mM}$ sodium acetate, $\mathrm{pH}$ 4.0. The colloidal gold was prepared with modifications as previously described (10). Membranes were incubated in staining solutions for 10-15 min, until colored spots appear. DMC staining was performed by sequential incubation in the Ferrozine/ferrous and ferrocyanide/ferric complexes (18). After staining the membranes, unbound dye was washed away with a 1-2-min incubation in dd- $\mathrm{H}_{2} \mathrm{O}$.

\section{Slot Blotting}

Slot blotting was performed using a Bio-Dot ${ }^{\circledR}$ SF vacuum apparatus (Bio$\mathrm{Rad}$ ) according to the manufacturer's instructions. Membranes were rehydrated with $100 \mu \mathrm{L} /$ well of dd- $\mathrm{H}_{2} \mathrm{O}$, samples were loaded and the wells rinsed. In all slot blot procedures, equal volumes of sample and wash buffers were used. Washes were always with dd $-\mathrm{H}_{2} \mathrm{O}$ for colloidal gold stain and 100 $\mathrm{mM}$ sodium acetate, $\mathrm{pH} 4.0$, for metal chelate stains.

For analysis of dynamic range and protein-to-protein variation, stock solutions of proteins were first prepared in $\mathrm{dd}-\mathrm{H}_{2} \mathrm{O}$ at concentrations ranging from 0.02 to $450 \mathrm{ng} / \mu \mathrm{L}$ and subsequently diluted with 4 volumes of the appropriate wash buffer. Five hundred microliters per well of sample were applied to yield total protein amounts ranging from $2.1 \mathrm{ng}$ to $45 \mu \mathrm{g}$. BSA was used to determine the dynamic linear range of each stain. For analysis of protein-toprotein variation, we used a five-point standard curve corresponding to the midpoint of the linear range for each stain. The proteins evaluated were BSA, gelatin, hemoglobin and ovalbumin. For both the Ferrozine/ferrous and DMC stains, the five standard curve points were $0.23,0.34,0.49,0.73$ and $1.1 \mu \mathrm{g}$. For colloidal gold, the points were 16, 21, 37, 53 and $68 \mathrm{ng}$.

For analysis of interfering agents, a quantity of BSA was chosen that roughly corresponded to the midpoint of the linear range for each stain. This ensured the detection of both false-positive and false-negative responses to the tested reagents (Table 1$)$. BSA $(0.70$ $\mu \mathrm{g}$ ) was used for the Ferrozine/ferrous chelate stain, $0.25 \mu \mathrm{g}$ for the DMC stain and $53 \mathrm{ng}$ for the colloidal gold. Proteins and interfering agents were prepared separately in $\mathrm{dd}-\mathrm{H}_{2} \mathrm{O}$ as $2 \times$ stocks. Equal volumes of each were combined and mixed on a vortex mixer. Solutions of the interfering agents were combined with equal volumes of dd$\mathrm{H}_{2} \mathrm{O}$. The proteins were also prepared in $\mathrm{dd}-\mathrm{H}_{2} \mathrm{O}$ in the absence of interfering agents to serve as controls. Samples were diluted 4-fold in the appropriate wash buffer and applied to the slot blot apparatus (500 $\mu \mathrm{L} /$ well). Following sample application to the slot blotter, membranes were blocked for 10-15 min with $0.1 \%$ PVP-40 in $100 \mathrm{mM}$ sodium acetate $\mathrm{pH} 4.0$ for the metal chelate stains and in PBS for colloidal gold. The staining and rinsing steps were identical to those of the dot blots described above.

\section{Densitometry}

Membranes were air-dried prior to analysis. Reflective imaging was employed for opaque nitrocellulose membranes using a document scanner (UC630 MaxColor ${ }^{\circledR}$; UMAX Data System, Hsinchu, Taiwan) interfaced with a Macintosh ${ }^{\circledR}$ Power PC 7100/66 (Apple Computer, Cupertino, CA, USA). A yellow cellophane photographic filter (Smith-Victor, Griffith, IN, USA) was used to enhance detection of the colored stains (3). A $3 \times 3$ pixel median filter was applied to the images to reduce noise (19). Quantitation was performed with NIH Image Version 1.57 public domain software developed by Dr. W. Rasband, Research Services Branch, NIMH (wayne@helix.nih. gov). Background subtraction was applied using the 2-D rolling ball algorithm within NIH Image; however, it had no effect on any of the assays (data not shown). NIH Image was also used to measure spot area for dot blots. Briefly, the scanned images were calibrated with a standard metric ruler, and the spot areas were obtained using the circular selection tool in NIH Image. Similar results were obtained utilizing the charge-coupled device (CCD)-based Bio Image system running on a Sun Microsystems SPARCstation ${ }^{\circledR}$ (Bio Image, Ann Arbor, MI, USA) (17).

To extend the dynamic range of the metal chelate stain, membranes were rendered clear for transmission imaging. Dry membranes were immersed in a small quantity of light white mineral 
oil and stored between two sheets of overhead transparency film. Transmission imaging was performed with a Videk ${ }^{\circledR}$ CCD camera (Eastman Kodak, Rochester, NY, USA) and Bio Image's Whole Band Analyzer software (17). Neutral density (0.3 optical density [OD]) and $600 \pm 70 \mathrm{~nm}$ band-pass filters were used to block excessive transmitted light and enhance the signal-tonoise ratio, respectively. A $3 \times 3$ pixel median filter was also applied to these images for noise reduction (18).

\section{BCA Assay}

The BCA assay was performed according to the method of Smith et al. using the Pierce Chemical (Rockford, IL, USA) $60^{\circ} \mathrm{C}$ enhanced protocol (23). For analysis of dynamic linear range and protein-to-protein variation, proteins were prepared at concentrations ranging from $100 \mathrm{ng} / 100 \mu \mathrm{L}$ to 300 $\mu \mathrm{g} / 100 \mu \mathrm{L}$ in dd- $\mathrm{H}_{2} \mathrm{O}$. BSA was used for analysis of the dynamic linear range $(n=4)$, while BSA, hemoglobin, ovalbumin and gelatin were used to evaluate protein-to-protein variation $(n=2)$. The five-point mid-range standard curve used to measure protein-to-protein variation was $5.7 \mu \mathrm{g} / 100 \mu \mathrm{L}, 6.7$ $\mu \mathrm{g} / 100 \mu \mathrm{L}, 10.0 \mu \mathrm{g} / 100 \mu \mathrm{L}, 15 \mu \mathrm{g} / 100$ $\mathrm{mL}$ and $23 \mu \mathrm{g} / 100 \mu \mathrm{L}$. Interfering agents $(n=2)$ were prepared as $2 \times$ stocks and mixed with equal volumes of $20 \mu \mathrm{g} / 100 \mu \mathrm{L}$ BSA (both in dd$\mathrm{H}_{2} \mathrm{O}$ ). Interfering agents were also evaluated without addition of protein. Control samples were prepared with and without $10 \mu \mathrm{g} / 100 \mu \mathrm{L}$ of BSA (final concentration) in dd- $\mathrm{H}_{2} \mathrm{O}$ in the absence of interfering agents.

\section{RESULTS AND DISCUSSION}

\section{Dot Blot Assay}

When integrated optical density is plotted against protein amount, a biphasic response is observed in dot-blot assays visualized with the Ferrozine/ferrous, DMC and colloidal gold stains (Figure 1B). Plots are characterized by a steep initial slope, followed by a shallower slope at higher protein concentrations. The phenomenon is observed with all proteins evaluated in this study and is illustrated with gelatin visualized with the DMC stain (Figure 1A). The initial slope, ranging from 5 to $340 \mathrm{ng}$, appears to be due to changes in stain intensity (Figure 1A, row 1). Stain intensity saturates at about $0.5 \mu \mathrm{g}$. The shallower slope, generated with protein amounts ranging from 0.5 to $10 \mu \mathrm{g}$, appears to result from progressive increases in spot area (Figure 1A, row 2). Plotting spot area as a function of the mean pixel density (average grey-scale intensity) verifies the cause of the two curves (data not shown). With 5 to 400 ng of applied protein, spot area remains constant at $1.2 \mathrm{~mm}^{2}$, but mean pixel density increases from 1 to 8 arbitrary units (AU). For protein amounts of 400 $\mathrm{ng}$ to $10 \mu \mathrm{g}$, the mean pixel density increases only slightly (from 8 to 9.5 AU), while spot area increases from 1.2 to $6 \mathrm{~mm}^{2}$. Tris- $\mathrm{HCl}$, sodium dodecyl sulfate (SDS) and Triton ${ }^{\circledR} \mathrm{X}-100$ increase spot area, while $\mathrm{MgCl}_{2}$ and $\mathrm{CaCl}_{2}$ decrease spot area in both colloidal gold- and DMC-stained dot blots (data not shown). It is expected that us- ing membranes with different protein binding and wetting capacities would alter the shape of solid-phase dot blot standard curves. Metal chelate stains can be used with a variety of membranes including nitrocellulose, PVDF and nylon (Reference 18, and unpublished observations).

\section{Linear Range}

Variation in spot spreading is effectively eliminated when a vacuum slotblot device is used, which restricts the protein application region to a defined area that cannot be altered by buffer composition or protein concentration. The device used in this study maintains a constant membrane surface area of $5.25 \mathrm{~mm}^{2}$ for protein binding. In the remainder of this paper, all comparisons of dynamic linear range, sensitivity, protein-to-protein variation and susceptibility to interfering agents utilize the device. Sensitivity is expressed as total protein per sample for all assays.

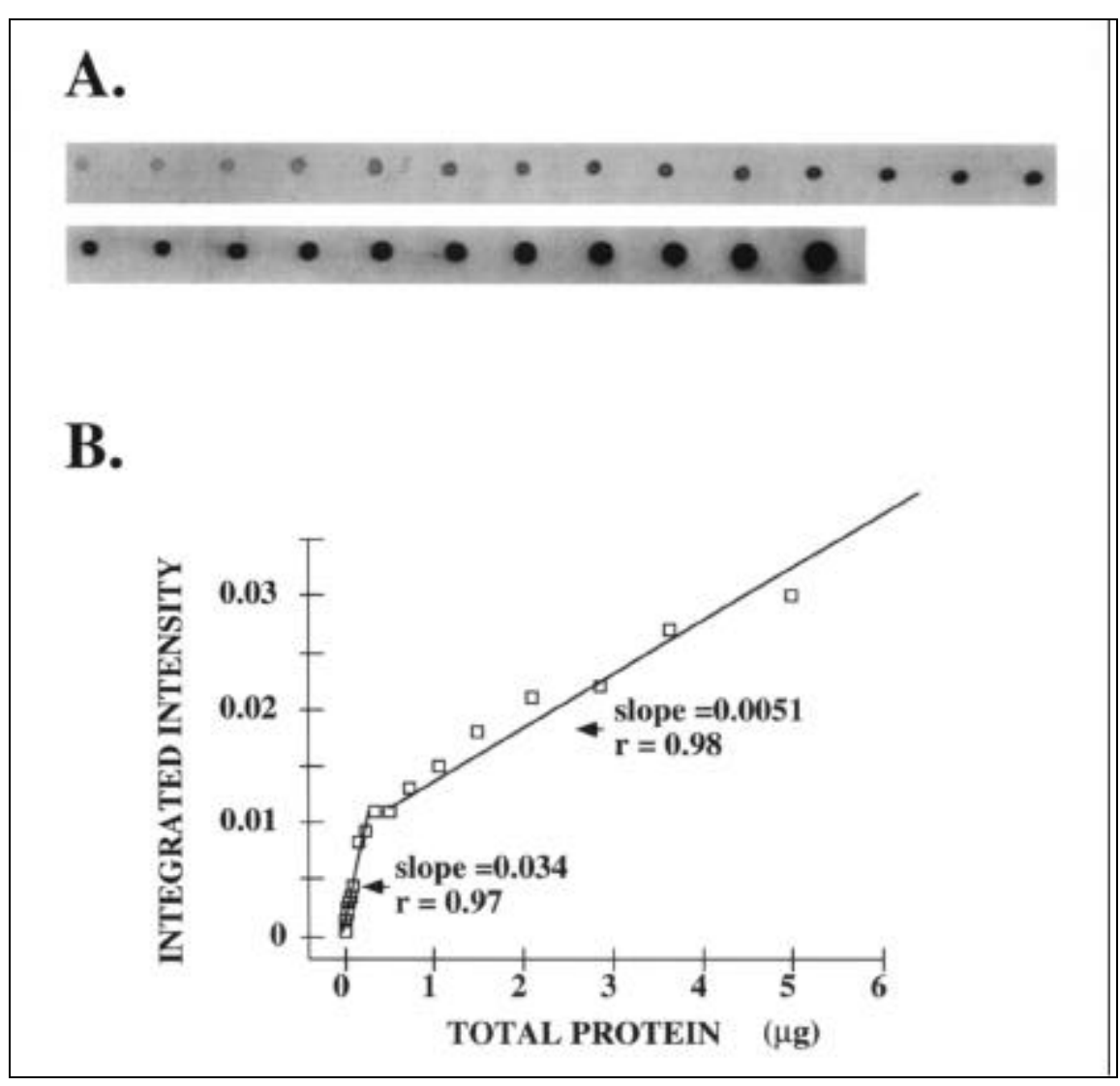

Figure 1. Evaluation of linearity of the solid-phase dot-blot assay using serially diluted bovine gelatin. Panel A: 5-340 ng (row 1) and 0.5-10 $\mu \mathrm{g}$ (row 2) of total protein were applied to nitrocellulose strips and visualized with the DMC stain. Panel B: Stained spots were quantified using computer-assisted image analysis, which revealed two distinct linear regions. 
Limits of linearity are determined by the following criterion: Standard deviations (error bars) of data points at the high and low end of standard curves are required to overlap the best fit line to be considered part of the range.

Evaluation of nitrocellulose membranes by reflectance imaging indicates that the dynamic linear range for protein detection is 0.15 to $1.5 \mu \mathrm{g}$ (10-fold range) for both the Ferrozine/ferrous (Figure 2A) and the DMC stains (data not shown). The dynamic linear range of the colloidal gold assay is 10.5 to 100.0 ng (10-fold) (Figure 2C). The linearity of the colloidal gold assay ( $r=$ 0.94) is poorer than the other solidphase and solution-phase assays $(r=$ 0.99 for the Ferrozine/ferrous chelate assay and $r=1.0$ for the BCA and DMC assays). The dynamic linear range for the BCA assay is $1.1 \mu \mathrm{g}$ to 49 $\mu \mathrm{g}$ (47-fold) (Figure 2D).

When high amounts of protein $(>1.6$ $\mu \mathrm{g})$ are applied to nitrocellulose membranes, staining is often observed on the membrane surface opposite the protein application. Though the protein on the reverse side of the membrane is stained by the solid-phase procedures, it is not detected by reflectance imaging, leading to low estimates of total protein amount. This problem can be circumvented by rendering membranes transparent and subsequently quantifying the stain by transmission imaging. The dynamic linear range of the DMC stain increases to 100-fold when nitrocellulose membranes are rendered transparent with mineral oil and imaged transmissively (0.10-10.0 $\mu \mathrm{g})$ (Figure 2B). Because of significant fading of the stain when membranes are rendered transparent, the dynamic linear range of the Ferrozine/ferrous chelate stain does not increase. Because of extensive stain smearing and flaking with higher amounts of protein, the linear dynamic range of the colloidal gold stain does not improve.

\section{Protein-to-Protein Variation}

Protein quantitation requires predictable relationships between the amount of protein and integrated OD (20). Ideally, all proteins should produce identical slopes and threshold responses when integrated OD is plotted as a

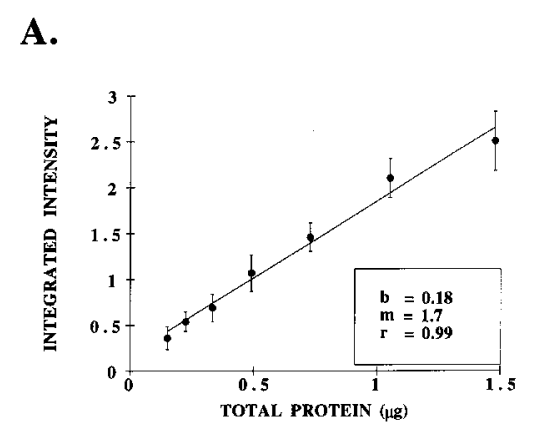

C.
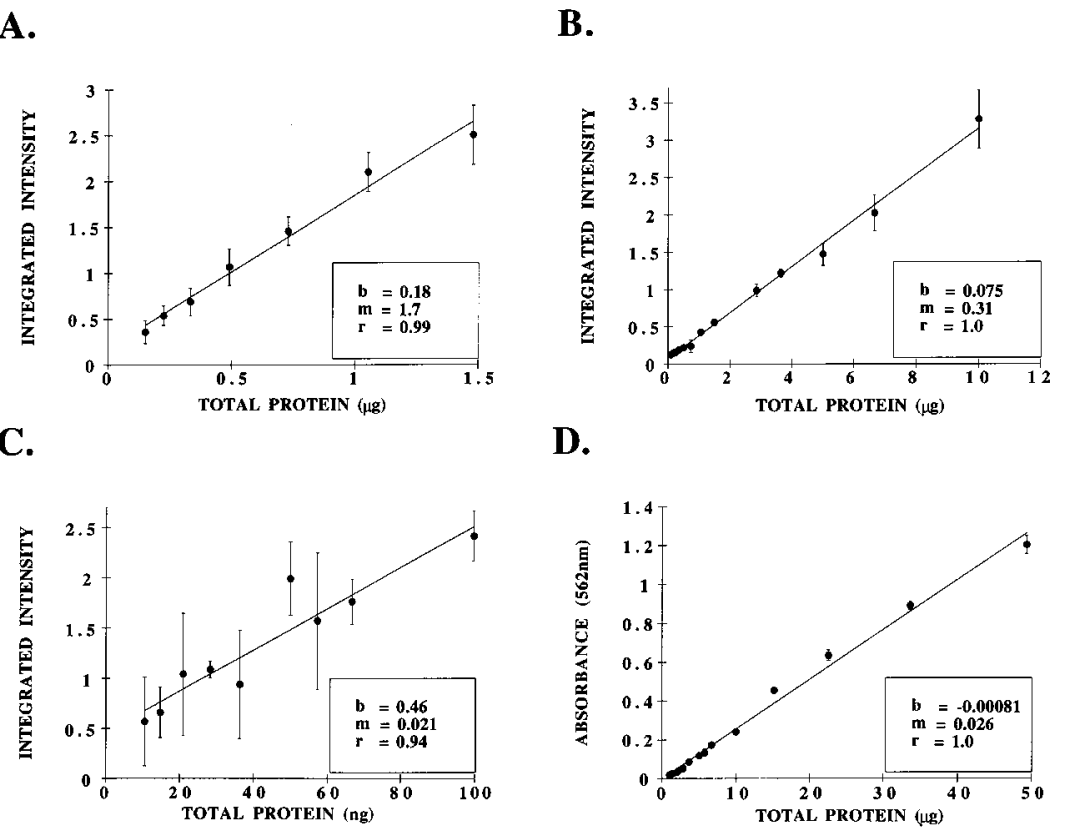

D.

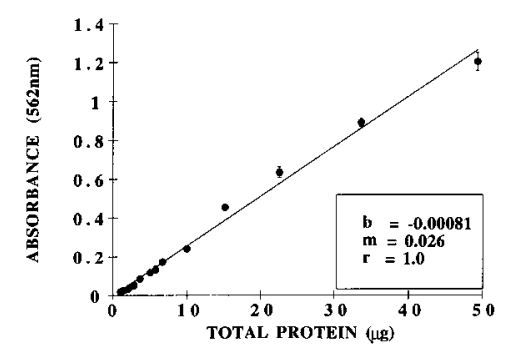

Figure 2. Determination of the dynamic linear range of various solid-phase and solution-based total protein assays using serially diluted BSA. Panel A: Ferrozine/ferrous chelate stain. Panel B: DMC stain. Panel C: Colloidal gold stain. Panel D: BCA assay. "b" is the Y-intercept, " $m$ " is the slope and " $\mathrm{r}$ " is the linear correlation coefficient of the best fit line through the data points. Error bars correspond to the standard deviation of each determination. Integrated OD is determined by transmission imaging in Panel B; and reflectance imaging, in panels A and C. 
Table 1. Evaluation of Interference from Commonly Used Chemical Agents

\begin{tabular}{|c|c|c|c|c|c|c|c|c|c|c|c|}
\hline \multirow[b]{2}{*}{ Agents } & & \multicolumn{10}{|c|}{$\%$ of Control \pm SD } \\
\hline & & \multicolumn{2}{|c|}{ Ferrozine } & \multicolumn{2}{|r|}{ DMC } & \multicolumn{3}{|c|}{ Gold } & \multicolumn{3}{|c|}{ BCA } \\
\hline \multicolumn{12}{|l|}{ Buffers } \\
\hline Tris-HCl & $\begin{array}{l}1 \mathrm{M} \\
0.1 \mathrm{M} \\
0.01 \mathrm{M}\end{array}$ & $\begin{array}{r}91 \\
92 \\
111\end{array}$ & $\begin{array}{rr} \pm & 12 \\
\pm & 4 \\
\pm & 6\end{array}$ & $\begin{array}{l}91 \\
96 \\
91\end{array}$ & $\begin{array}{r} \pm 15 \\
\pm 8 \\
\pm 8\end{array}$ & $\begin{array}{l}233 \\
243 \\
174\end{array}$ & $\begin{array}{l} \pm \\
\pm \\
\pm\end{array}$ & $\begin{array}{r}47 \\
35 \\
5\end{array}$ & $\begin{array}{r}28 \\
102 \\
105\end{array}$ & $\begin{array}{l} \pm \\
\pm \\
\pm\end{array}$ & $\begin{array}{l}4 \\
3 \\
2\end{array}$ \\
\hline Glycine & $\begin{array}{l}1 \mathrm{M} \\
0.5 \mathrm{M} \\
0.1 \mathrm{M}\end{array}$ & $\begin{array}{l}91 \\
92 \\
91\end{array}$ & $\begin{array}{rr} \pm & 12 \\
\pm & 6 \\
\pm & 6\end{array}$ & $\begin{array}{l}110 \\
124 \\
104\end{array}$ & $\begin{array}{r} \pm 11 \\
\pm 13 \\
\pm \quad 7\end{array}$ & $\begin{array}{l}275 \\
161 \\
202\end{array}$ & $\begin{array}{l} \pm 4 \\
\pm 1 \\
\pm 1\end{array}$ & $\begin{array}{l}415 \\
178 \\
131\end{array}$ & $\begin{array}{r}44 \\
76 \\
117\end{array}$ & $\begin{array}{l} \pm 0 . \\
\pm 0.2 \\
\pm\end{array}$ & $\begin{array}{l}2 \\
2 \\
1\end{array}$ \\
\hline \multicolumn{12}{|l|}{ Salts } \\
\hline$\left(\mathrm{NH}_{4}\right)_{2} \mathrm{SO}_{4}$ & $\begin{array}{l}20 \% \\
10 \% \\
0.2 \%\end{array}$ & $\begin{array}{l}117 \\
113 \\
105\end{array}$ & $\begin{array}{rr} \pm & 15 \\
\pm & 5 \\
\pm & 14\end{array}$ & $\begin{array}{l}103 \\
111 \\
101\end{array}$ & $\begin{array}{lr} \pm & 13 \\
\pm & 6 \\
\pm & 10\end{array}$ & $\begin{array}{l}220 \\
249 \\
233\end{array}$ & $\begin{array}{l} \pm \\
\pm \\
\pm\end{array}$ & $\begin{array}{l}64 \\
62 \\
14\end{array}$ & $\begin{array}{r}50 \\
80 \\
110\end{array}$ & $\begin{array}{l} \pm \\
\pm \\
\pm 0\end{array}$ & $\begin{array}{l}2 \\
4 \\
1\end{array}$ \\
\hline $\mathrm{KCl}$ & $\begin{array}{l}100 \mathrm{mM} \\
10 \mathrm{mM} \\
1 \mathrm{mM}\end{array}$ & $\begin{array}{r}92 \\
110 \\
120\end{array}$ & $\begin{array}{rr} \pm & 13 \\
\pm & 13 \\
\pm & 5\end{array}$ & $\begin{array}{r}98 \\
98 \\
100\end{array}$ & $\begin{array}{l} \pm 15 \\
\pm 25 \\
\pm 20\end{array}$ & $\begin{array}{l}194 \\
252 \\
180\end{array}$ & $\begin{array}{l} \pm \\
\pm \\
\pm\end{array}$ & $\begin{array}{l}38 \\
68 \\
48\end{array}$ & $\begin{array}{l}105 \\
102 \\
107\end{array}$ & $\begin{array}{l} \pm \\
\pm \\
\pm\end{array}$ & $\begin{array}{l}5 \\
7 \\
4\end{array}$ \\
\hline $\mathrm{MgCl}_{2}$ & $\begin{array}{l}100 \mathrm{mM} \\
10 \mathrm{mM} \\
1 \mathrm{mM}\end{array}$ & $\begin{array}{l}117 \\
119 \\
109\end{array}$ & $\begin{array}{rr} \pm & 13 \\
\pm & 6 \\
\pm & 8\end{array}$ & $\begin{array}{l}116 \\
115 \\
100\end{array}$ & $\begin{array}{l} \pm 26 \\
\pm \quad 4 \\
\pm 22\end{array}$ & $\begin{array}{l}178 \\
227 \\
229\end{array}$ & $\begin{array}{l} \pm \\
\pm \\
\pm\end{array}$ & $\begin{array}{l}61 \\
27 \\
20\end{array}$ & $\begin{array}{r}88 \\
102 \\
103\end{array}$ & $\begin{array}{l} \pm \\
\pm \\
\pm\end{array}$ & $\begin{array}{l}4 \\
6 \\
6\end{array}$ \\
\hline \multicolumn{12}{|l|}{ Detergents } \\
\hline Triton X-100 & $\begin{array}{l}10 \% \\
1 \% \\
0.1 \%\end{array}$ & $\begin{array}{l}19 \\
10 \\
16\end{array}$ & 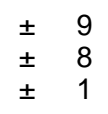 & $\begin{array}{l}18 \\
27 \\
46\end{array}$ & $\begin{array}{l} \pm 8 \\
\pm 12 \\
\pm 14\end{array}$ & $\begin{array}{l}153 \\
164 \\
112\end{array}$ & $\begin{array}{l} \pm \\
\pm \\
\pm\end{array}$ & $\begin{array}{r}9 \\
36 \\
8\end{array}$ & $\begin{array}{l}188 \\
121 \\
118\end{array}$ & $\begin{array}{l} \pm \\
\pm \\
\pm\end{array}$ & $\begin{array}{l}5 \\
5 \\
1\end{array}$ \\
\hline SDS & $\begin{array}{l}10 \% \\
1 \% \\
0.1 \%\end{array}$ & $\begin{array}{r}57 \\
81 \\
107\end{array}$ & $\begin{array}{l} \pm \quad 6 \\
\pm \quad 4 \\
\pm \quad 4\end{array}$ & $\begin{array}{l}154 \\
129 \\
144\end{array}$ & $\begin{array}{r} \pm 10 \\
\pm 8 \\
\pm \quad 8\end{array}$ & $\begin{array}{r}8 \\
22 \\
22\end{array}$ & $\begin{array}{l} \pm \\
\pm \\
\pm\end{array}$ & $\begin{array}{r}4 \\
11 \\
11\end{array}$ & $\begin{array}{l}117 \\
115 \\
108\end{array}$ & $\begin{array}{l} \pm \\
\pm 0 . \\
\pm\end{array}$ & $\begin{array}{l}2 \\
2 \\
7\end{array}$ \\
\hline Tween ${ }^{\circledR} 20$ & $\begin{array}{l}10 \% \\
1 \% \\
0.1 \%\end{array}$ & $\begin{array}{r}17 \\
17 \\
4\end{array}$ & $\begin{array}{lr} \pm & 6 \\
\pm & 15 \\
\pm & 1\end{array}$ & $\begin{array}{l}28 \\
21 \\
34\end{array}$ & $\begin{array}{lr} \pm & 6 \\
\pm & 12 \\
\pm & 21\end{array}$ & $\begin{array}{l}233 \\
282 \\
240\end{array}$ & $\begin{array}{l} \pm \\
\pm \\
\pm 1\end{array}$ & $\begin{array}{r}36 \\
77 \\
108\end{array}$ & $\begin{array}{l}195 \\
125 \\
115\end{array}$ & $\begin{array}{l} \pm \\
\pm \\
\pm\end{array}$ & $\begin{array}{l}2 \\
1 \\
2\end{array}$ \\
\hline \multicolumn{12}{|l|}{ Reductants } \\
\hline DTT & $\begin{array}{l}10 \mathrm{mM} \\
1 \mathrm{mM} \\
0.1 \mathrm{mM}\end{array}$ & $\begin{array}{l}107 \\
111 \\
101\end{array}$ & $\begin{array}{rr} \pm & 5 \\
\pm & 15 \\
\pm & 14\end{array}$ & $\begin{array}{l}116 \\
104 \\
104\end{array}$ & $\begin{array}{l} \pm 15 \\
\pm 19 \\
\pm 11\end{array}$ & $\begin{array}{l}107 \\
175 \\
183\end{array}$ & $\begin{array}{l} \pm 1 \\
\pm \\
\pm 1\end{array}$ & $\begin{array}{r}131 \\
93 \\
113\end{array}$ & $\begin{array}{l}685 \\
385 \\
114\end{array}$ & $\begin{array}{l} \pm 1 \\
\pm 10 \\
\pm\end{array}$ & $\begin{array}{l}6 \\
0 \\
3\end{array}$ \\
\hline BME & $\begin{array}{l}10 \% \\
1 \% \\
0.1 \%\end{array}$ & $\begin{array}{r}91 \\
108 \\
112\end{array}$ & $\begin{array}{rr} \pm & 13 \\
\pm & 13 \\
\pm & 9\end{array}$ & $\begin{array}{r}111 \\
97 \\
108\end{array}$ & $\begin{array}{l} \pm 14 \\
\pm 13 \\
\pm 26\end{array}$ & $\begin{array}{r}20 \\
43 \\
141\end{array}$ & $\begin{array}{l} \pm \\
\pm \\
\pm\end{array}$ & $\begin{array}{r}7 \\
10 \\
21\end{array}$ & $\begin{array}{r}0.0 \\
653 \\
653\end{array}$ & $\begin{array}{l} \pm 0 . \\
\pm \quad \\
\pm 1\end{array}$ & \\
\hline \multicolumn{12}{|l|}{ Miscellaneous } \\
\hline EDTA & $\begin{array}{l}100 \mathrm{mM} \\
10 \mathrm{mM} \\
1 \mathrm{mM}\end{array}$ & $\begin{array}{l}100 \\
110 \\
103\end{array}$ & $\begin{array}{l} \pm \quad 9 \\
\pm \quad 5 \\
\pm \quad 6\end{array}$ & $\begin{array}{r}108 \\
96 \\
117\end{array}$ & $\begin{array}{l} \pm 11 \\
\pm 11 \\
\pm \quad 14\end{array}$ & $\begin{array}{r}162 \\
101 \\
37\end{array}$ & $\begin{array}{l} \pm \\
\pm \\
\pm\end{array}$ & $\begin{array}{r}32 \\
19 \\
4\end{array}$ & $\begin{array}{r}0.0 \\
99 \\
103\end{array}$ & $\begin{array}{l} \pm \\
\pm \\
\pm \\
\pm\end{array}$ & \\
\hline Sucrose & $\begin{array}{l}40 \% \\
20 \% \\
0.4 \%\end{array}$ & $\begin{array}{r}100 \\
96 \\
98\end{array}$ & $\begin{array}{l} \pm \quad 5 \\
\pm \quad 8 \\
\pm \quad 5\end{array}$ & $\begin{array}{l}107 \\
108 \\
101\end{array}$ & $\begin{array}{lr} \pm \quad 4 \\
\pm 15 \\
\pm 13\end{array}$ & $\begin{array}{l}77 \\
92 \\
80\end{array}$ & $\begin{array}{l} \pm \\
\pm \\
\pm\end{array}$ & $\begin{array}{r}8 \\
12 \\
22\end{array}$ & $\begin{array}{l}209 \\
163 \\
116\end{array}$ & $\begin{array}{l} \pm 0 . \\
\pm \\
\pm\end{array}$ & $\begin{array}{l}2 \\
3 \\
2\end{array}$ \\
\hline Glycerol & $\begin{array}{l}20 \% \\
10 \% \\
0.1 \%\end{array}$ & $\begin{array}{r}118 \\
102 \\
94\end{array}$ & $\begin{array}{lr} \pm & 9 \\
\pm & 11 \\
\pm & 10\end{array}$ & $\begin{array}{l}136 \\
117 \\
117\end{array}$ & $\begin{array}{lr} \pm & 16 \\
\pm & 7 \\
\pm & 16\end{array}$ & $\begin{array}{l}292 \\
232 \\
216\end{array}$ & $\begin{array}{l} \pm \\
\pm \\
\pm\end{array}$ & $\begin{array}{l}97 \\
75 \\
35\end{array}$ & $\begin{array}{l}637 \\
513 \\
144\end{array}$ & $\begin{array}{l} \pm \\
\pm 17 \\
\pm\end{array}$ & $\begin{array}{l}4 \\
7 \\
2\end{array}$ \\
\hline PVP-40 & $\begin{array}{l}0.1 \% \\
0.01 \% \\
0.001 \%\end{array}$ & $\begin{array}{l}15 \\
22 \\
68\end{array}$ & $\begin{array}{rr} \pm & 14 \\
\pm & 5 \\
\pm & 12\end{array}$ & $\begin{array}{l}48 \\
67 \\
86\end{array}$ & $\begin{array}{l} \pm 9 \\
\pm \quad 15 \\
\pm 16\end{array}$ & $\begin{array}{r}132 \\
128 \\
92\end{array}$ & $\begin{array}{l} \pm \\
\pm \\
\pm\end{array}$ & $\begin{array}{l}61 \\
61 \\
16\end{array}$ & $\begin{array}{l}104 \\
104 \\
105\end{array}$ & $\begin{array}{l} \pm \\
\pm \\
\pm\end{array}$ & $\begin{array}{l}3 \\
3 \\
4\end{array}$ \\
\hline Ampholyte & $\begin{array}{l}1 \% \\
0.1 \% \\
0.01 \%\end{array}$ & $\begin{array}{r}95 \\
99 \\
110\end{array}$ & $\begin{array}{rr} \pm & 12 \\
\pm & 3 \\
\pm & 7\end{array}$ & $\begin{array}{l}120 \\
122 \\
122\end{array}$ & $\begin{array}{l} \pm 5 \\
\pm 13 \\
\pm 13\end{array}$ & $\begin{array}{r}149 \\
79 \\
62\end{array}$ & $\begin{array}{l} \pm \\
\pm \\
\pm\end{array}$ & $\begin{array}{l}26 \\
25 \\
12\end{array}$ & $\begin{array}{r}113 \\
100 \\
92\end{array}$ & $\begin{array}{l} \pm \\
\pm \\
\pm\end{array}$ & $\begin{array}{l}7 \\
5 \\
4\end{array}$ \\
\hline
\end{tabular}


function of protein amount. In reality, slope and threshold values for different proteins often vary, making it difficult to assign absolute mass to a given protein based upon measurable integrated OD. Numerous dye-binding protein assays are characterized by individual proteins producing linear standard curves, but with slopes and threshold detection levels that differ for each protein. This is due to differences in the mole percentage of basic amino acids in each protein $(5,18,25,27)$. For truly quantitative estimates of protein amount, a standard curve must be produced for each protein assayed.

Protein-to-protein variation for the solid-phase and solution-phase assays are assessed using standard curves generated for four known proteins (Figure $3)$. The curves are evaluated by comparing the mean integrated OD values (solid-phase assays) or absorbance values (solution-based assay) obtained for ovalbumin, hemoglobin and gelatin with the values obtained from equal amounts of BSA. The colloidal gold stain significantly underestimates the amount of ovalbumin, yielding a mean ratio of $0.3 \pm 0.2$ relative to $\mathrm{BSA}$. The DMC stain also slightly underestimates $(0.7 \pm 0.10)$, while the Ferrozine/ferrous chelate and the BCA methods accurately estimate, the amount of ovalbumin $(1.0 \pm 0.1)$. The Ferrozine/ ferrous chelate, DMC and colloidal gold stains overestimate hemoglobin $(1.5 \pm 0.3,1.2 \pm 0.2$ and $1.7 \pm 0.6$, respectively) and gelatin ( $1.5 \pm 0.3,1.5 \pm$ 0.2 and $2.0 \pm 0.3$, respectively). The BCA assay accurately estimates the amount of hemoglobin $(1.0 \pm 0.1)$, but underestimates the amount of gelatin $(0.7 \pm 0.0)$.

Next, the slopes from the calculated best line fits for each standard curve are compared to the slope of the BSA curve. The colloidal gold and Ferro- zine/ferrous chelate stains show the highest protein-to-protein variation with respect to this parameter. Relative to BSA, the colloidal gold yields standardized slope values of $-0.1,0.6$ and 1.3 for ovalbumin, hemoglobin and gelatin, respectively. The Ferrozine/ferrous chelate produces a steeper slope with hemoglobin (1.5), but ovalbumin and gelatin are similar to the BSA reference ( 0.8 and 0.9 , respectively). The DMC and BCA methods demonstrate the lowest protein-to-protein variation. The DMC stain produces slope values of $0.9,0.9$ and 0.8 for ovalbumin, hemoglobin and gelatin, respectively, whereas the BCA assay yields values of 0.8 for all three proteins when compared to the BSA reference. Evaluation of the standard deviations obtained from measuring the four test proteins indicates that the BCA assay has the lowest standard deviation value $(6 \%)$, followed by the DMC stain (9\%), 
Ferrozine stain (12\%) and colloidal gold stain $(23 \%)$.

Thus, the DMC assay displays relatively little protein-to-protein variation with respect to slope of the standard curve, but does exhibit moderate variation in threshold detection sensitivity. The BCA assay also exhibits low variation in slope; and, among the five proteins evaluated, threshold detection sensitivity differs substantially only for gelatin. With respect to both threshold detection sensitivity and slope, the Ferrozine/ferrous chelate stain exhibits moderate, while the colloidal gold stain exhibits high, protein-to-protein variation. Ovalbumin, in particular, is very poorly stained using the colloidal gold method.

Although four model proteins are evaluated in this paper, the DMC protocol effectively stains $800-1000$ proteins in complex cell lysates separated by two-dimensional gel electrophoresis and electroblotted to nitrocellulose membrane, with a sensitivity similar to silver staining (18). The DMC stain is more sensitive and exhibits lower protein-toprotein variation than other commonly used dye-binding stains (Ponceau red, Fast green and amido black) (18). In addition, the stain is suitable for quantifying small peptides (leucine enkephalin and apidaecin) (18).

\section{Interfering Agents}

In solid-phase protein assays, dilute protein samples are easily concentrated onto the membrane, since multiple sample applications can be performed to accommodate large volumes. Solutionbased assays detect only a finite protein concentration. If the detection limit for a solution-based assay is reached, the sample-to-assay reagent ratio must be increased or the sample must be concentrated. Increasing sample volume is likely to increase chemical interference from buffer components (23). Solutionbased assays, however, generally involve fewer handling steps where protein losses may occur.

The solid-phase and solution-based assays were examined with respect to susceptibility to interfering agents (Table 1). The number of agents tested was extensive, but easily interpreted by defining significant interference as a 2fold increase or decrease in integrated
OD. The Ferrozine/ferrous and DMC assays are significantly inhibited by $0.1 \%-10 \%$ Triton X-100 and Tween 20. PVP-40 also inhibits the Ferrozine/ ferrous chelate stain at concentrations of $0.01 \%-0.1 \%(\mathrm{wt} / \mathrm{vol})$, whereas the DMC stain is affected only at a concentration of $0.1 \%$. Neither of the metal chelate stains generates significant false-positive signals with any of the tested agents. Experiments performed in the absence of protein further substantiate the lack of false-positive signals produced by the agents (data not shown). The colloidal gold stain is sensitive to interference from most agents at the concentrations listed in Table 1. Interference is primarily manifested as increased signal, though SDS inhibits staining at all concentrations tested $(0.1 \%-10 \% \mathrm{wt} / \mathrm{vol})$ and BME inhibits staining at $1 \%-10 \%$ (vol/vol). Falsepositive staining is observed, in the absence of protein, with $10 \%$ SDS, $1-10$ $\mathrm{mM}$ dithiotheitol (DTT) and 1\%-10\% BME (data not shown). DTT and BME cause the colloidal gold to change from red to black and result in excessive band smearing in the presence or absence of protein. Color development in the BCA assay is inhibited by $1 \mathrm{M}$ Tris$\mathrm{HCl}, 1 \mathrm{M}$ glycine, 20\% ammonium sulfate (wt/vol), 10\% BME and $100 \mathrm{mM}$ EDTA. False-positive signals are produced with 1-10 mM DTT, $0.1 \%-1 \%$ BME, $40 \%$ sucrose and 10\%-20\% glycerol. Thus, of the assays evaluated in this study, the Ferrozine/ferrous and DMC assays display the lowest susceptibility to chemical interference, with only non-ionic detergents and PVP-40 inhibiting staining. This is reasonable since binding to nitrocellulose membranes is thought to occur largely through hydrophobic interactions (11). The inability of PVP-40 to be stained by the DMC procedure and its effectiveness as a membrane-blocking agent are key to protein sequencing and immunoblotting applications (18). A related stain, copper phthalocyanine $3,4^{\prime}, 4^{\prime \prime}, 4^{\prime \prime}$-tetrasulfonic acid, shares many properties with our stain but binds avidly to PVP (10).

\section{CONCLUSION}

The DMC stain is resistant to interference from common chemical reagents, has low protein-to-protein

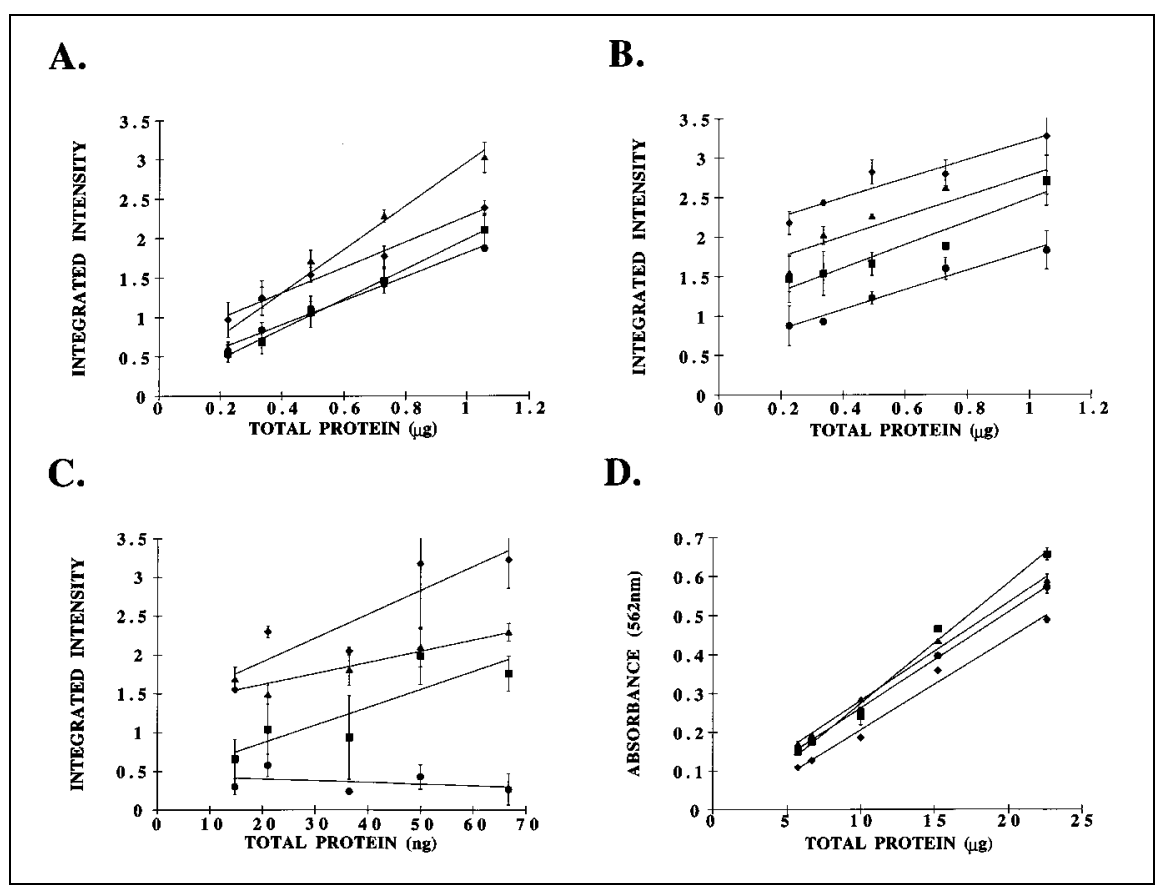

Figure 3. Response curves for different proteins using various solid-phase and solution-based total protein assays. Panel A: Ferrozine/ferrous chelate stain. Panel B: DMC stain. Panel C: Colloidal gold stain. Panel D: BCA assay. The proteins evaluated are bovine serum albumin (squares), ovalbumin (circles), gelatin (diamonds) and hemoglobin (triangles). Error bars correspond to the standard deviation of each determination. Integrated OD is determined by reflectance imaging in Panels A, B and C. 
variation, is sensitive and reproducible, and displays a 100-fold dynamic linear range. The DMC stain is readily quantified using an inexpensive document scanner interfaced with a personal computer. In addition, a standard yellow cellophane photographic filter and a slot-blotting apparatus are required. Using the slot-blot apparatus, 48 samples can be applied to the nitrocellulose in less than $30 \mathrm{~min}$, and staining requires another $30 \mathrm{~min}$. Our laboratory routinely utilizes the staining procedure to standardize samples in immunoblotting. Cell lysates or subcellular fractions are conveniently stained for total protein, quantified, destained and reprobed with a specific antibody detection system on a single nitrocellulose membrane.

\section{ACKNOWLEDGMENTS}

This project was supported in part by a grant from the Boston University Center for Photonics Research, as well as NIH Grants HL-43875 and 48553.

\section{REFERENCES}

1.Bradford, M. 1976. A rapid and sensitive method for the quantitation of microgram quantities of protein utilizing the principle of protein-dye binding. Anal. Biochem. 72:248254.

2.Clark, S. 1984. Determination of membrane protein concentration, p. 149-161. In J. Venter and L. Harrison (Eds.), Receptor Purification Procedures. Alan R. Liss, New York.

3.Donovan, R., C. Robison and B. Glick. 1994. Detection enhancement of computer images of bands from Western blots using a grayscale scanner. BioTechniques 17:660-661.

4.Esen, A. 1978. A simple method for quantitative, semiquantitative, and qualitative assay of protein. Anal. Biochem. 89:264-273.

5.Fazekas de St. Groth, S., R. Webster and A. Datyner. 1963. Two new staining procedures for quantitative estimation of proteins on electrophoretic strips. Biochim. Biophys. Acta 71:377-391.

6.Gates, R. 1991. Elimination of interfering substances in the presence of detergent in the bicinchoninic acid protein assay. Anal. Biochem. 196:290-295.

7.Ghosh, S., S. Gepstein, J. Heikkila and E. Dumbroff. 1988. Use of a scanning densitometer or an ELISA plate reader for measurement of nanogram amounts of protein in crude extracts from biological tissues. Anal. Biochem. 169:227-233.

8.Gracia, E. and F. Fernandez-Belda. 1992. Ponceau $\mathrm{S}$ as a dye for quantitative protein assay. Its use in the presence of Triton X-100. Biochem. Int. 27:725-733.
9.Guttenberger, M., V. Neuhoff and R. Hampp. 1991. A dot-blot assay for quantitation of nanogram amounts of protein in the presence of carrier ampholytes and other possibly interfering substances. Anal. Biochem. 196:99-103.

10.Horisberger, M. and J. Rosset. 1977. Colloidal gold, a useful marker for transmission and scanning electron microscopy. J. Histochem. Cytochem. 25:295-305.

11.Hunter, J. and S. Hunter. 1987. Quantification of proteins in the low nanogram range by staining with the colloidal gold stain $\mathrm{Au}-$ roDye. Anal. Biochem. 164:430-433.

12.Li, K., P. Geraerts, R. van Elk and J. Joose. 1989. Quantification of proteins in the subnanogram and nanogram range: comparison of the AuroDye, FerriDye, and India ink staining methods. Anal. Biochem. 182:44-47.

13.Minamide, L. and J. Bamburg. 1990. A filter paper dye-binding assay for quantitative determination of protein without interference from reducing agents or detergents. Anal. Biochem. 190:66-70.

14.Murthy, M. and T. Leroux. 1975. Determination of protein in extracts containing interfering substances and in radioactive samples following scintillation counting. Anal. Biochem. 64:18-29.

15.Nakamura, K., T. Tanaka, A. Kuwahara and K. Takeo. 1985. Microassay for proteins on nitrocellulose filter using protein dye-staining procedure. Anal. Biochem. 148:311-319.

16.Orsonneau, J., P. Douet, C. Massoubre, P. Lustenberger and S. Bernard. 1989. An improved pyrogallol red-molybdate method for determining total urinary protein. Clin. Chem. 35:2233-2236.

17.Patton, W. 1995. Biologist's perspective on analytical imaging systems as applied to protein gel electrophoresis. J. Chrom. A, 698:5587.

18.Patton, W., L. Lam, Q. Su, M. Lui, H. Erdjument-Bromage and P. Tempst. 1994. Metal chelates as reversible stains for detection of electroblotted proteins: application to protein microsequencing and immunoblotting. Anal. Biochem. 220:324-335.

19.Patton, W. and P. Tempst. 1993. Enhancing spot detection and reducing noise from digitized electrophoretic gel images using area processing filters. Electrophoresis 14:650658.

20.Rodriguez, L., D. Gersten, L. Ramagli and D. Johnston. 1993. Towards stoichiometric silver staining of proteins resolved in complex two-dimensional electrophoresis gels: realtime analysis of pattern development. Electrophoresis 14:628-637.

21.Said-Fernandez, S., M. Gonzalez-Garza, B. Mata-Cardenas and L. Navarro-Marmolejo. 1990. A multipurpose solid-phase method for protein determination with Coomassie brilliant blue G-250. Anal. Biochem. 191:119126.

22.Sheffield, J., D. Graff and H. Li. 1987. A solid-phase method for the quantitation of protein in the presence of sodium dodecyl sulfate and other interfering substances. Anal. Biochem. 166:49-54

23.Smith, P., R. Krohn, G. Hermanson, A. Mallia, F. Gartner, M. Provenzano, E. Fuji- moto, N. Goeke, B. Olson and D. Klenk. 1985. Measurement of protein using bicinchoninic acid. Anal. Biochem. 150:76-85.

24.Sportsman, R. and J. Elder. 1984. A microanalytical protein assay using laser densitometry. Anal. Biochem. 139:298-300.

25.Tal, M., A. Silberstein and E. Nusser. 1985. Why does Coomassie Brilliant Blue R interact differently with different proteins? A partial answer. J. Biol. Chem. 260:9976-9980.

26.Watanabe, N., S. Kamei, A. Ohkubo, M. Yamamanaka, S. Ohsawa, K. Makino and K. Tokuda. 1986. Urinary protein as measured with a pyrogallol red-molybdate complex, manually and in a Hitachi 726 automated analyzer. Clin. Chem. 32:1551-1554.

27.Wirth, P. and A. Romano. 1995. Staining methods in gel electrophoresis, including the use of multiple detection methods. J. Chromatogr. 698:123-143.

Received 17 November 1995; accepted 29 March 1996.

Address correspondence to:

Wayne F. Patton

Microvascular Research Laboratory

Boston University

5 Cummington Street

Boston, MA 02215, USA

Internet:patton@acs.bu.edu 